\title{
Trends in biomass, density and diversity of North Sea macrofauna
}

\author{
C. Heip, D. Basford, J. A. Craeymeersch, \\ J.-M. Dewarumez, J. Dörjes, P. de Wilde, G. Duineveld, \\ A. Eleftheriou, P. M. J. Herman, U. Niermann, \\ P. Kingston, A. Künitzer, E. Rachor, H. Rumohr, \\ K. Soetaert, and T. Soltwedel
}

\begin{abstract}
Heip, C., Basford, D., Craeymeersch, J. A., Dewarumez, J.-M., Dörjes, J., de Wilde, P., Duineveld, G., Eleftheriou, A., Herman, P. M. J., Niermann, U., Kingston, P., Künitzer, A., Rachor, E., Rumohr, H., Soetaert, K., and Soltwedel, K. 1992. Trends in biomass, density and diversity of North Sea macrofauna. - ICES J. mar. Sci., 49; 13-22.

Total biomass and biomass of large taxonomic groups (polychaetes, molluscs, crustaceans, echinoderms) and species diversity of the macrofauna were determined for almost 200 North Sea stations sampled synoptically by seven vessels during Spring 1986 and for 120 additional stations sampled in earlier years by the Marine Laboratory in Aberdeen. There exists a clear and significant decreasing trend in biomass with latitude, both in total biomass and for the different taxonomic groups. Apart from latitude, sediment composition and chlorophyll $a$ content of the sediment also infuence total biomass and biomass of most groups significantly. Biomass increases consistently in finer sediments and sediments with a higher chlorophyll $a$ content. The same trends are found for the results within laboratories. Some interaction exists, indicating weak laboratory and zonal effects. Diversity, as measured by Hill's diversity index $N_{1}=\left(\exp H^{\prime}\right)$ shows a clear and significant trend with latitude. Towards the north of the North Sea diversity increases considerably. The trend is also found for laboratories separately and is everywhere equally strong. Also longitude and depth show an effect on diversity. Sediment variables have no clear influence on diversity. Other diversity measures show the same Irend but are more variable than $\mathrm{N}_{1}$. Total density tends to increase towards the north but sediment related variables have a larger influence. Mean individual weight becomes considerably smaller towards the northern part of the North Sea.
\end{abstract}

Key words: macrobenthos; density; diversity; biomass; latitudinal gradients; North Sea.

Received 23 May 1991; accepted 11 November 1991.

C. Heip, J. A. Craeymeersch, P. M. J. Herman, and K. Soetaert: Netherlands Institute of Ecology, Centre for Marine and Coastal Ecology, Yerseke, The Netherlands. D. Basford, and A Eleftheriou Marine Laboratory, Aberdeen, Scotland. A Künitzer, and E. Rachor: Alfred Wegener Institute. Bremerhaven, Germany. U. Niermann: Biologische Anstalt Heigoland, Hamburg, Germany. J. Dörjes: Senckenberg Institute, Wilhelmshaven, Germany. H. Rumohr: Institut für Meereskunde, Kiel, Germany. P. Kingston: Institute for Offshore Engineering, Heriot-Wau University, Edinburgh, Scotland. P. de Wilde, and G. Duineveld: Netherlands Institute for Sea Research, Texel. The Netherlands, J. M. Dewarumez: Institut de Biologie Marine, Wimereux, France. T. Soltwedel: Institüt für Hydrobiologie, University of Hamburg. Germany.

\section{Introduction}

Macrobenthos of the North Sea has been the subject of investigation since the early years of the century, when Gilson (1907) and Petersen (1914) studied Belgian and Danish coastal waters respectively. The studies of Petersen have had an especially important impact on marine ecology in general, mainly through the introduction of the concept of marine communities. This concept has found wide application in ecological monitoring. The fact that spatially coherent species assemblages can be delimited using objective methods has proved to be

$1054-3139 / 92 / 010013+10 \$ 03.00 / 0$ of great significance in monitoring the impact on the sedimentary environment of human activities through pollution by oil and sewage, dredging, beam trawling and sand and gravel exploitation. Whether these species assemblages are structured through species interactions or by common environmental requirements has been the subject of a long and intense debate, but is immaterial in the context of monitoring. The question that arises is whether such patterns are sufficiently constant to serve as yardsticks against which the magnitude and sign of changes can be evaluated. However, elucidation of the causal factors will strengthen the 
explanatory power of these synecological, multivariate analyses.

Besides changes in species assemblages, human activity also causes changes in other community attributes such as density, biomass and diversity. An intermediate disturbance seems to raise both biomass (e.g. Beukema \& Cadée, 1986; Cederwall \& Elmgren, 1980) and diversity (e.g. Lambshead, 1986; Pearson et al., 1983). As the magnitude of the disturbance further increases, dramatic changes in the benthos may occur in which species diversity decreases but abundance of smaller species increases, until with still further increasing disturbance a total collapse occurs (e.g. Pearson \& Rosenberg, 1978; Rosenberg, 1985; Niermann et al., 1990). Monitoring the benthos gives a direct way of quantifying these effects.

Changes in benthic communities may occur on different spatial (and temporal) scales, perhaps varying from one to hundreds of kilometres, and may be anthropogenic or due to natural causes. In the marine environment changes due to human activity are in most cases restricted to spatial scales that are much smaller than those dealt with in this study, i.e. the whole of the North Sea. If patterns in species distribution and community attributes exist on these scales, they are most likely linked with natural processes. The measurement of benthic abundance and biomass is also important for more fundamental studies of energy flow through ecosystems. A direct link between surface primary production and benthic metabolism in shallow water (Hargrave, 1973) and between the proportion of primary produced organic matter reaching the sea floor and depth (Suess, 1980) is now well documented.

This paper describes patterns in biomass, density and diversity of the macrobenthic infauna of the whole North Sea with a characteristic length scale of the order of tens of hundreds of kilometres. Künitzer et al. (in press) describe the faunal assemblages from the same samples and both papers should be consulted together.

\section{Materials and methods}

\section{Sampling}

The present results are part of the North Sea Benthos Survey executed in April-May 1986 when 197 stations were sampled covering the ICES grid from $51^{\circ} \mathrm{N}$ to $58^{\circ} \mathrm{N}$ and from $2^{\circ} 30^{\prime} \mathrm{W}$ to $8^{\circ} 15^{\prime} \mathrm{E}$. At each of these stations five box cores if possible, but sometimes Van Veen grabs, were taken. The complete list of replicates, dates, samples and stations has been reported to ICES (Anonymous, 1986) and is available from the first author on request. Most of the stations were analysed for macrofauna biomass, density and species composition, for meiofauna density and copepod species composition, for sediment grain size analysis, protein content, plant pigment content, organic matter and a series of heavy metals. Most of these data are published elsewhere in this volume.

The data from the northern North Sea have been gathered during eight cruises from 1980 to 1985 , always in spring or early summer (Basford \& Eleftheriou, 1988; Basford et al., 1989; Eleftheriou \& Basford, 1989). The area covered extends between $56^{\circ} 15^{\prime} \mathrm{N}$ and $60^{\circ} 45^{\prime} \mathrm{N}$ and $3^{\circ} 30^{\prime} \mathrm{W}$ and $7^{\circ} 30^{\prime} \mathrm{E}$. A total of 119 stations were sampled for macrofauna (Basford et al., 1990).

The data presented here are based on 175 stations sampled of the ICES North Sea Benthos Survey (48 of them sampled by two different laboratories), and 61 stations of the northern North Sea, viz. those stations lying on an extrapolated ICES grid (seven of them overlapping with ICES stations). Thus, total density, total biomass and diversity has been determined for 229 stations. On stations sampled twice, the average of the values of the two laboratories was used.

\section{Intercalibration}

Two intercalibration exercises have been performed, the results of both have been presented to ICES (Heip et al., 1985; Duineveld \& Witte, 1987) and will be briefly repeated here.

The first intercalibration exercise aimed at intercomparison of sampling gear and processing methods (sieving, washing, fixation etc.). Samples were taken at two stations, Molengat $\left(53^{\circ} 01.8^{\prime} \mathrm{N}\right.$ and $4^{\circ} 41.4^{\prime} \mathrm{E}$, depth $8.5 \mathrm{~m}$, sand) and Meta II $\left(53^{\circ} 42.2^{\prime} \mathrm{N}\right.$ and $4^{\circ} 30^{\circ} \mathrm{E}$, depth $37 \mathrm{~m}$, muddy sand) with the usual gear of each institute and with one standardized set. The routinely used gear varied from $30 \mathrm{~kg}$ Van Veen grabs to $700 \mathrm{~kg}$ box-corers. The processing of the sample on board of the vessel was also very different (fixation prior to sieving or not, round woven holes or square punched holes in the sieve etc.). The results clearly showed that the different procedures used by different laboratories resulted in different results even when the same macrofauna community was sampled (drift of the ship while sampling may have caused some of these differences). Differences when using one's own gear were also very significant. In the case of total density, the penetration of the gear was clearly the crucial factor in the sandy station Molengat. Neither density nor biomass estimates differed signifcantly in the muddy sand station Meta II, irrespective of using a $30 \mathrm{~kg}$ Van Veen or a $700 \mathrm{~kg}$ box-corer. Measures of diversity depend on taxonomic skill but also on gear used. The small Reineck box-corer consistently gave lower estimates of species number. When it was eliminated from the analysis the results for Molengat did not differ significantly, but the difference for Meta II remained very highly significant. This was due to taxonomic processing and to different sieving methods. The results from this intercalibration exercise clearly showed 
that comparisons of macrofauna data are very difficult and that standardization of gear and processing as well as taxonomic intercalibration will be essential for future comparative studies.

Ash-free dry weight was standardized after an intercalibration exercise which again clearly showed the necessity of a standardized method. When the different methods traditionally used in each laboratory were applied to samples of the mollusc Macoma balthica, both the slope and the intercept of the regression line between weight and length were significantly different. When the standard methods proposed by the Benthos Ecology Working Group of ICES (Rumohr, 1990) were used, results between laboratories did not differ (Duineveld \& Witte, 1987).

\section{Diversity}

As measures of faunal diversities the following Hill's diversity numbers (Hill, 1973) were used:

$\mathrm{N}_{0}=$ Number of species (species richness)

$\mathrm{N}_{1}=\exp \left(\mathrm{H}^{\prime}\right)$ where $\mathrm{H}^{\prime}$ is the Shannon-Wiener diversity (calculated with natural logarithms)

$\mathbf{N}_{2}=1 / \mathrm{SI}$ where SI is Simpson's dominance index (calculated with the revised formula of Pielou, 1969 see Heip et al., 1988)

$\mathrm{N}_{x}=1 / \mathrm{DI}$ where DI is the dominance index (relative abundance of the most common species)

These diversity indices were calculated on the raw, purified (see Künitzer et al., 1992) data set. However, as sample size influences the different measures in a different way (Soetaert and Heip, 1990) they were also calculated for a standard sample size. From each sample 50 individuals were drawn at random, and the diversity indices calculated. This was repeated 50 times. Arithmetic means of the 50 values were used as the standardized diversity estimate for the sample.

\section{Biomass}

Depending on the institute the biomass was measured either directly as ash-free dry weight or calculated from wet weight using appropriate conversion factors (Rumohr et al., 1987).

\section{Statistical analysis}

The faunal data (total biomass, total density, individual weight and diversity) and environmental variables (latitude, longitude, depth, median grain size and silt, chla and POC content of the sediment) were compared by multiple linear regression.

\section{Results}

The total macrofauna biomass and the biomass of the major phyla (Annelida, Mollusca, Arthropoda, Echinodermata, Rest) at each station are shown in Figures 1 and 2 . The average total biomass is $7 \mathrm{~g}$ ash-free dry weight $\left(\right.$ AFDW) $\mathrm{m}^{-2}$ (standard error $=7.6$ )

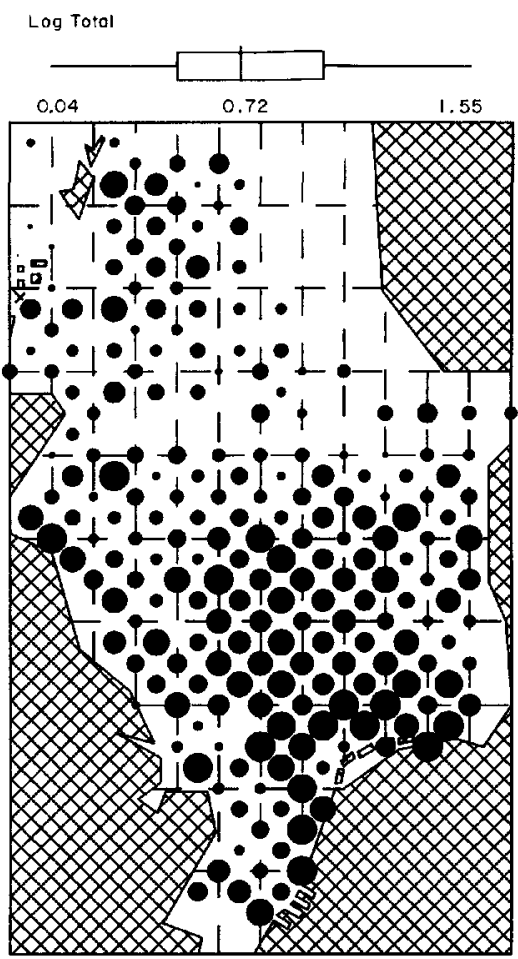

Figure 1. Log of total macrofauna biomass (ash-free dry weight $\mathrm{m}^{-2}$ ) of the North Sea. The radius of the black circles is proportional to the log-transformed biomass within the range of the box-and-whisker plots at the top of the figure. Outliers (in the box-and-whisker plots indicated by points) have the same radius as the maximum or minimum value.

Total biomass (after log transformations) shows a clear and significant trend with latitude. This is shown in Figure 3 where for each degree latitude the mean \pm standard error of the biomass is expressed. Towards the north biomass decreases considerably. The major shift is not caused by one major taxonomical group overtaking another as 
(a) Log Echinodermato

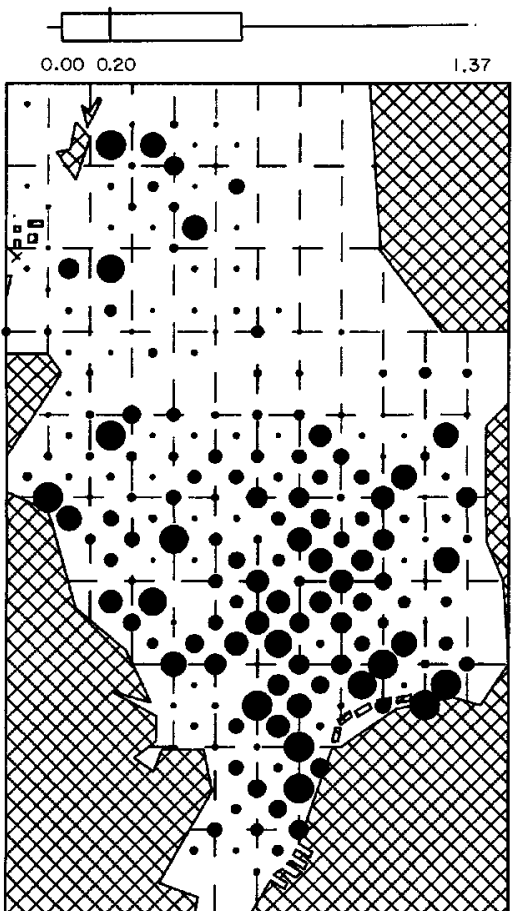

(b) Log Crustoceo

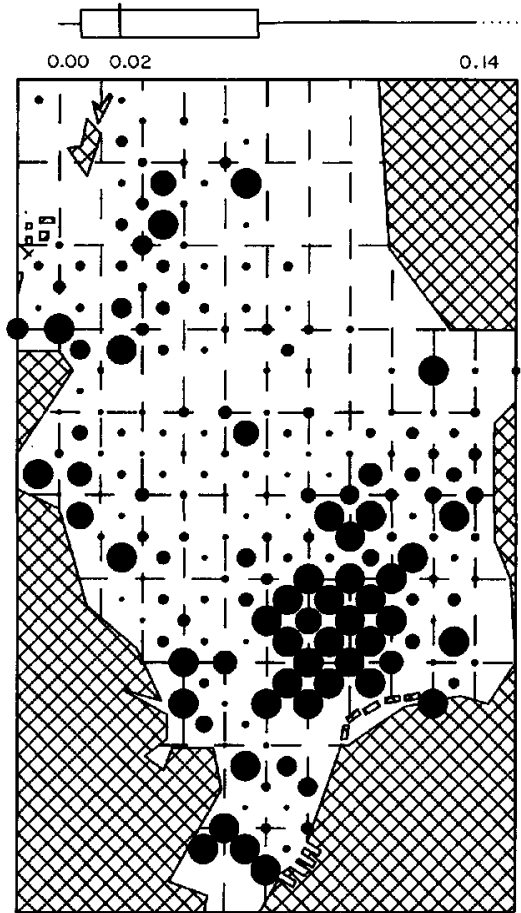

Figure 2 (a) and (b)

Figure 2. Log of total biomass of the major taxonomic groups of the macrobenthos in the North Sea (ash-free dry weight $\mathrm{m}^{-2}$ ). (a) Echinodermata. (b) Crustacea. (c) Polychaeta. (d) Mollusca.

one goes north (Fig. 4). Rather, the same trends seem to be operating in the different groups.

Apart from latitude sediment composition (logarithm of fraction smaller than $62 \mu \mathrm{m}$ ) and chlorophyll $a$ content of the sediment also influence the total biomass, and the biomass of most separate groups significantly (Table 1). In these regressions the following variables were tested: longitude, latitude, median grain size, silt content, percentage organic carbon, chlorophyll $a$ content and depth. The best model in most cases was using latitude plus one or two sediment variables, in which case latitude accounts always for a larger part of the variance. For biomass of molluscs, the model with latitude and chlorophyll $a$ accounts for a smaller proportion of variance (squared multiple $r=0.100$ ) than the model with silt content and chlorophyll $a$ as predictors (squared multiple $\mathrm{r}=0.147$ ).

Especially with silt content of the sediment, the relation may be non-linear. Figure 5 shows this relation, clarificd by a smoothing technique called distance-weighted least squares smoothing (McLain, 1974; Wilkinson, 1988). The locally weighted smooth line clearly suggests that biomass increases with silt content between 0.1 and $1 \%$, remains relatively uncorrelated for silt content between 1 and $10 \%$, and decreases with silt content for very fine sediments (silt content $>10 \%$ ). This type of relationship is not uncommon in macrobenthos. The relationship of (log transformed) total biomass with (log transformed) chlorophyll $a$ content of the sediment is relatively linear (Fig. 6).

For total biomass the same trends are found within each "laboratory zone" see Künitzer (in press) for a map of laboratory zones, although there is indication of a (not very pronounced) interaction, indicating that the strength of the trend depends on the laboratory or on the zone in the North Sea where one looks.

Diversity, as measured by Hill's diversity index $\mathrm{N}_{1}$, $=\exp \left(\mathrm{H}^{\prime}\right)$, shows a significant trend with latitude (Fig. 7). 

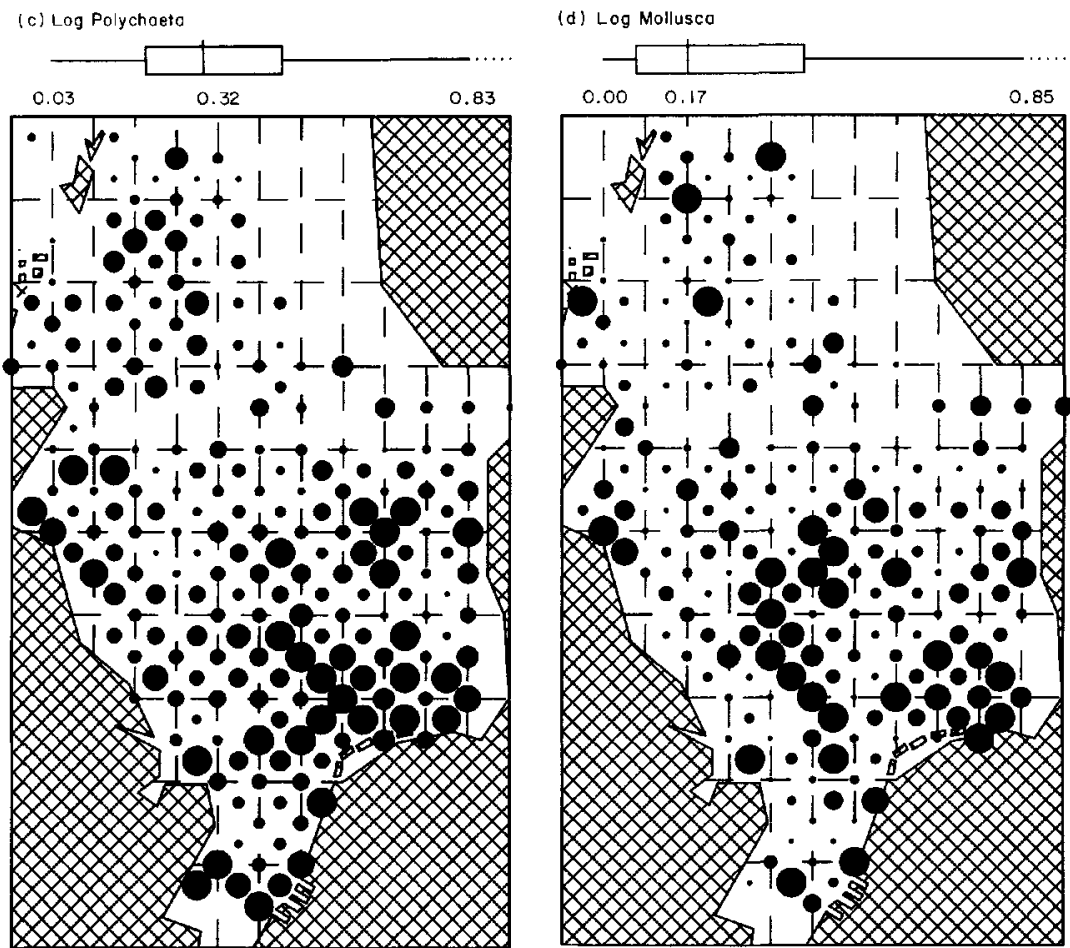

Figure 2 (c) and (d)

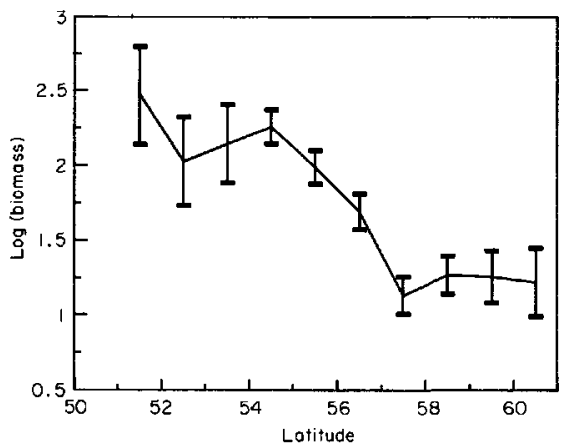

Figure 3. Log of total macrofauna biomass (AFDW $\mathrm{m}^{-2}$ ) as a function of latitude.

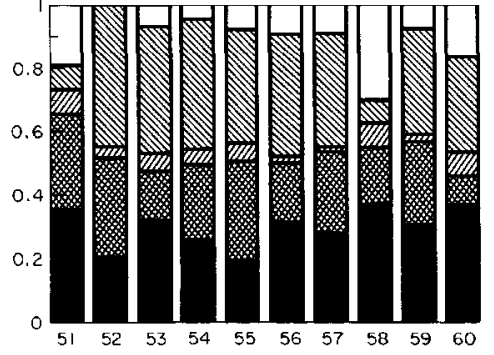

Figure 4. Fraction of total biomass represented by the large taxonomic groups of the macrofauna. Polychaeta, Mollusca, Crustacea, Echinodermata, $\square$ remainder.

Towards the north of the North Sea diversity increases considerably. The trend is found within each "laboratory zone", and is about as strong everywhere. Analysis of 
Table 1. Multiple linear regression of (log transformed) biomass and environmental variables * Indicates that the environmental variable has a significant $(5 \%)$ independent contribution to the explanation of the dependent variable in the "best" model (i.e. in the model with all partial regression coefficients significantly different from zero and the highest squared multiple r).

\begin{tabular}{lcccc}
\hline & Latitude & Chla & Log (silt) & Depth \\
\hline Total & $*$ & $*$ & $*$ & \\
$\begin{array}{l}\text { Mollusca } \\
\text { Polychaeta }\end{array}$ & $*$ & $*$ & $*$ & $*$ \\
$\begin{array}{l}\text { Echinodermat } \\
\text { Crustacea }\end{array}$ & $*$ & $*$ & & \\
Rest & $*$ & & $*$ & \\
\hline
\end{tabular}

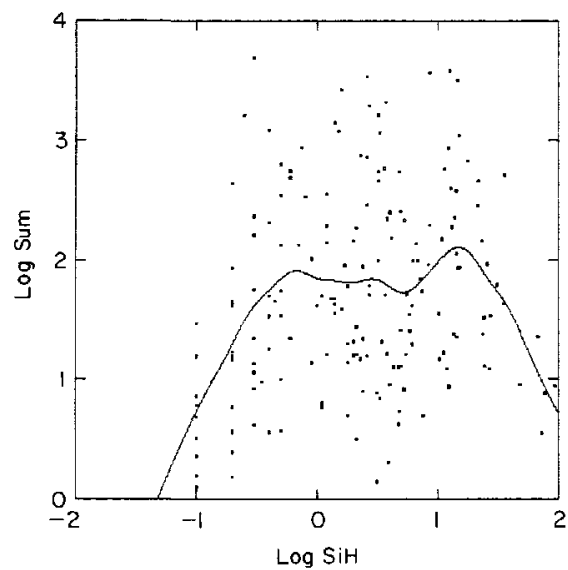

Figure 5. Relationship of (log transformed) total biomass ( AFDW m ${ }^{-2}$ ) with (log transformed) $\%$ sediment $<62 \mu \mathrm{m}$ The smooth line is obtained by distance weighted least squares smoothing.

covariance showed no significant $(0.05$ level) interaction between laboratory and slope of the regression on latitude. On the other hand, different laboratories had significantly different intercepts for the relation with latitude. In view of the non-random distribution of the laboratory zones over the North Sea, it is not clear, however, whether this reflects true differences between the laboratories. Besides latitude, both depth and longitude show an effect in the separate regressions. Other environmental variables have no clear influence. The "best" model has both latitude and longitude as predictors. Other diversity measures $\left(\mathrm{N}_{0}, \mathrm{~N}_{2}, \mathrm{~N}_{x}\right)$ show the same trend (they are strongly correlated) but are subject to more variability than $\mathrm{N}_{1}$.

The effect of different sample sizes on the estimation of diversity indices was not very important for $\mathbf{N}_{1}$. After

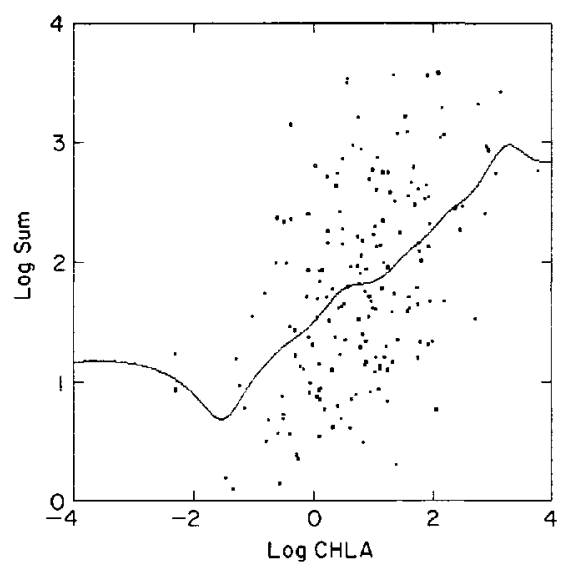

Figure 6. Relationship of (log transformed) total biomass ( AFDW $\mathrm{m}^{-2}$ ) with (log transformed) chlorophyll $a$ content of the sediment ( $\mu \mathrm{g}$ chla $a$ per $5 \mathrm{~cm}^{-2}$ sediment). The smooth line is obtained by distance weighted least squares smoothing.

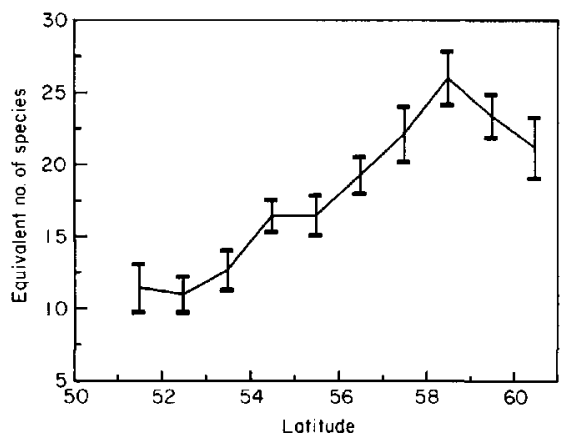

Figure 7. Diversity (Hill number $\mathbf{N}_{1}$ expressed in equivalent number of species) as a function of latitude.

standardization to 50 individuals, its relation with latitude is not too different from the relationship shown in Figure 7. In accordance with the conclusions of Soetaert and Heip (1990), the effect is more pronounced on $N_{0}$, the number of species. Here much variability is taken away by standardization, and a very clear relationship with latitude ensues (Fig. 8). Both latitude and longitude and depth show an effect on the standardized number of 


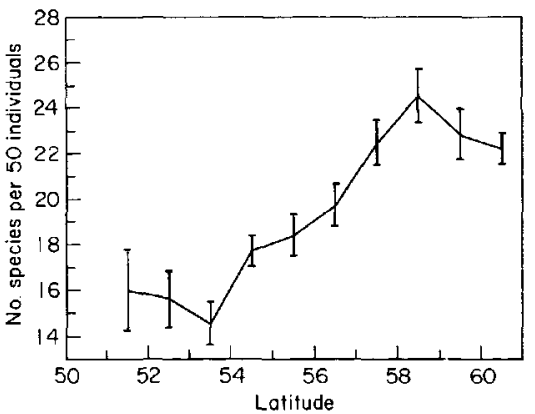

Figure 8. Diversity (number of species per 50 individuals) as a function of latitude.

species, and all regression coefficients remain significantly different from zero in a multiple regression.

Density shows a less clear gradient with latitude. There is a tendency for density to increase towards the north (Fig. 9), but the trend is less clear and less linear than for biomass and diversity. Using latitude, chlorophyll $a$ content and median grain size as predictors gives the "best" model, and sediment accounts for a larger part of the variance than latitude.

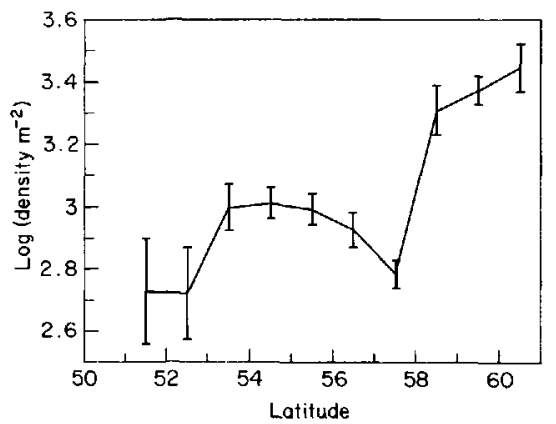

Figure 9. $\log$ density (numbers $\mathrm{m}^{-2}$ ) as a function of latitude

The mean weight of the individuals, obtained by dividing total biomass by total density in each sample, also shows a very clear gradient with latitude (Fig. 10). Towards the northern part of the North Sea, individual size becomes considerably smaller: the difference in mean weight is much more than one order of magnitude. Adding sediment as predictor variable does not increase the squared multiple $r(0.371$ for the model with latitude and chla, 0.364 using only latitude).

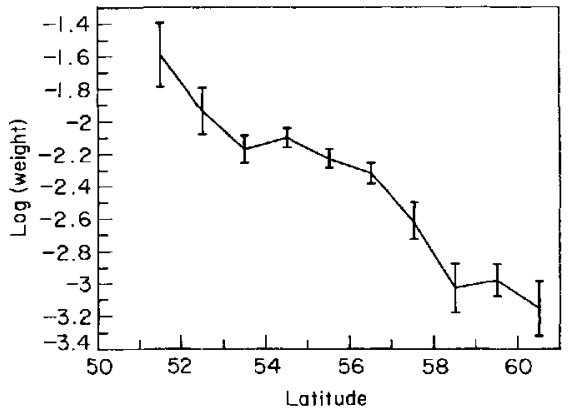

Figure 10. Log individual weight ( $\mathrm{g} \mathrm{AFDW}$ ind ${ }^{-1}$ ) as a function of latitude.

\section{Discussion}

Although an extensive literature exists on species assemblages of restricted areas of the North Sea (see e.g. Govaere et al., 1980 for the Southern Bight and Salzwedel et al., 1985 for the German Bight) and some synthesis for the whole North Sea has been attempted (Stephen, 1933; Glémarec, 1973) there are only a few data on density, biomass and diversity (Rachor, 1982) and no realistic estimates for the whole North Sea existed until now. Moreover, biomass values were underestimated by the use of less efficient grabs (Zijlstra, 1988). Rachor (1982) summarized available biomass values and estimated the average biomass as $3.2 \mathrm{AFDW} \mathrm{m}^{-2}$. This value corresponded to the stock as used in the North Sea model of Andersen and Ursin (1977), but was about twice as high as biomass values used by Steele $(1967,1974)$. But, as all these estimates are based on limited data Rachor (1982) stressed the importance of a "quasisynoptic map of biomass distribution". Such a mapping has now been done, and the mean biomass appears to be at least - because April is commonly assumed to be a moment of minimum biomass - twice as high as estimated before. However, some predicted general features such as highest biomass stocks in the whole infralittoral étage (Glémarec, 1973) and in the coastal etage near the Scottish coast and south and east of the Shetlands have been confirmed.

The results from the survey show clearly that large scale patterns in the structure (diversity) and functional attributes (abundance, average weight and biomass) of macrobenthic communities in the North Sea exist and that part of the variance in these variables can be explained by the environmental factors measured. Diversity, as measured by a standardized species richness and by $\exp \left(\mathrm{H}^{\prime}\right)$, shows a clear and nearly linear increase with latitude. Ursin (1960), in a study of the echinoderm fauna between $54^{\circ}$ and $57^{\circ} \mathrm{N}$, also found diversity to be highest in the northern part, independently of the type of sediment. 
Depth and longitude also show an independent effect on diversity. Total biomass decreases northward and is a function of latitude, the amount of chlorophyll $a$ and the proportion of silt (particles smaller than $62 \mu \mathrm{m}$ ) in the sediment. These same factors also explain the biomass of the different taxonomic groups, but differently. Zijlstra (1988), from more limited information, tentatively concluded that macrofauna biomass tends to decline with depth and appears to be related to sediment type. There is a tendency for density to increase towards the north. This agrees with the conclusion of Zijlstra (1988) who found "the highest numbers unexpectedly occurring in the two deeper étages". The trend is, however, not clear and sediment seems to be more important. Mean individual weight again shows a remarkable nearly linear decrease with latitude.

The northern North Sea data have been obtained over different years and using a sieve of $0.5 \mathrm{~mm}$ mesh size. The effect of mesh width may especially complicate the comparison with the NSBS data. However, since one would expect a smaller average size and individual weight resulting from this difference, the observed trends would not have been different if a larger mesh size had been used.

Principal components analysis on the environmental variables shows a good correlation between longitude, depth and latitude. Median grain size and silt content are also correlated. Chlorophyll $a$ is weakly correlated with the first group. For the interpretation of the observed trends with latitude it is useful to consider the general trend of both water depth and longitude with latitude. Latitude and depth are nearly linearly related - apart from some irregularities the North Sea gently slopes from a shallow southern part to a deeper northern part. While north of the 58 degree latitude almost all stations sampled are situated to the west of the 2nd degree longitude, the southern North Sea (i.e. south of the 54 degree latitude) is situated east of the 2nd degree longitude. For biomass, density and individual weight, latitude invariably explained more variation than depth. Thus, latitude shows the effects of both depth and another, unfortunately unknown, variable.

The general direction of the circulation in the North Sea varies only little with seasons (Backhaus, 1989) and is in general cyclonic. Atlantic waters entering the North Sea from the north do not reach the continental coastline but turn gradually eastward towards the Jutland coast and the Skagerrak where they merge with the southern Atlantic inflow through the Channel. All water masses leave the North Sea along the west coast of Norway. The effect of longitude on diversity possibly shows the importance of current patterns on species distributions. Indeed, several species, including e.g. Leucon nasica and Thyasira ferruginea, are restricted to the western part of the northern North Sea (Künitzer et al., in press).

It is also conceivable that the colonization of the North Sea both from the north and the south after the last Ice
Age is still reflected in latitudinal patterns of species occurrences and thus diversity. During the Quarternary glacial period, the whole area was covered with ice. After the last glacial period around 15000 years ago (Wurm glaciation), the sea penetrated into the North Sea area from the north, and the northern part of it became part of a glacial sea known as the Yoldia Sea. Between the Boreal and Atlanticum ( $5500 \mathrm{BC}$ ), the sea level was about $17 \mathrm{~m}$ lower than today, the North Sea was a shallow basin with several shoals and the Channel was not open. As late as $2000 \mathrm{BC}$ the Channel was still a small river-like water, In the beginning of the Atlanticum the present shape of the North Sea formed, except for the west coast of Jutland and Dutch German coast. Subsequently the sea level rose $15 \mathrm{~m}$, the Dogger Bank disappeared and the Channel reached its full extent. This means that the fauna in many parts of the North Sea is younger than around 7000 years and that the southern element, which penetrated through the Channel, is no more than 4000 years old. Such a young fauna is unlikely to have yet stabilized and attained its highest diversity.

Effects of storms on benthic communities have not been thoroughly investigated but may restrict the occurrence of sensitive species to waters deeper than say $30 \mathrm{~m}$.

The correlation between benthic biomass and chlorophyll $a$ in sediments certainly indicates a link with surface productivity, especially since the correlation does not exist with total pigment concentration. A survey by Owens et al. (1990) covering the whole North Sea in July 1987 showed high chlorophyll and primary production occurring in a band around the continental and UK coasts more or less consistent with the CZCS images. CZCS images tend to show higher apparent chlorophyll concentrations in the coastal zones of southern England and the continent up to Denmark and Norway and perhaps over the Dogger Bank. But primary production cycles do not peak at the same moment in the north and the south (Colebrook \& Robinson, 1965). In the southern North Sea the cycle peaks in early April, in the Central North Sea perhaps slightly later. In the northern North Sea production reached its maximum at the beginning of May. Whereas in the southern North Sea production appears to be continuous throughout summer, in the northern North Sea the blooms are restricted to the spring. The differences in time of onset are associated with increasing water depth, and the delay must be a consequence of later stabilization (Cushing, 1983). It is generally believed that the seasonal increase in solar radiation and the vertical stability of the water are the two most important factors (Colebrook \& Robinson, 1965). North Sea waters become stratified in summer north of a latitude of about $54^{\circ} \mathrm{N}$, except for the German Bight and Danish coast. The impact of stratification on food input to the benthos may be one of the most important factors explaining large scale patterns observed in this study. The differences in primary production cycles in the northern 
and southern North Sea possibly have larger effects than a different chlorophyll $a$ content of the sediments. This may be the reason why latitude, in itself not a controlling factor, invariably explained more variation in biomass than e.g. depth and chlorophyll $a$, and why animals become smaller towards the north.

Beside chlorophyll $a$, the silt content of the sediments accounts for a large part of the variance in biomass and density. Suspended solids enter the North Sea from the north (North Atlantic Ocean) and from the south (the Channel), from land and by erosion (resuspension) of sediments. Transport is mainly determined by wind and density driven currents and by residual tidal currents. Most of the material deposited in the south is from the Channel, with some from the Rhine and from the German rivers; the material in the North comes from the Atlantic (Puls, 1987). Erosion and deposition of solids depend on the bed shear velocity, which is much stronger along the coasts in the south of the North Sea and on the Dogger Bank than elsewhere. The transport follows the general movement of the water, and highest concentrations of suspended matter are found along the coasts of the Southern Bight and further north along the eastern side of the southern North Sea (Eisma and Irion, 1988).

Although human impact around point sources such as sewage outlets and oil platforms is known to affect the benthos, these effects are localized. Effects of fisheries are probably much more widespread but difficult to quantify. Beam-trawling in particular is thought to have large effects on benthic communities, including disappearance of long-lived species such as Aphrodite aculeata and Arctica islandica, but whether such an effect exists is unclear from our data. Eutrophication and oxygen deficiency has been documented for the Skagerrak and the German Bight. Rachor (1990) reports an increase of 50\% of macrofauna biomass in the German Bight between 1924 and 1984, especially due to increases in polychaetes and molluscs. Oxygen deficiency can cause mass mortality in benthos over large areas but recovery may be rapid (Niermann et al., 1990).

\section{Acknowledgements}

The vessels which participated in the North Sea Benthos Survey were RVs "Littorina" (University of Kiel), "Friedrich Heincke" (Biologische Anstalt Helgoland), "Senckenberg" (Senckenberg Institute, Wilhelmshaven), "Victor Hensen" (Institut für Meeresforschung now Alfred Wegener Institute, Bremerhaven), "Aurelia" (Netherlands Institute for Sea Research), "Tyro" (Netherlands Marine Research Foundation), "Holland" (Rijkswaterstaat) and "Belgica" (Belgian Ministry of Public Health). We gratefully acknowledge the help of the different authorities in providing us with shiptime and the crews of all these vessels. We are also grateful to the North
Sea Directorate of the Ministry of Public Works and Transport (Rijkswaterstaat) in the Netherlands and the Delta Institute for Hydrobiological Research for much needed financial support through grants for Karline Soetaert and Johan Craeymeersch.

\section{References}

Andersen, K. P., and Ursin, E. 1977. A multispecies extension to the Beverton and Holt theory of fishing, with accounts of phosphorus circulation and primary production. Meddelelser fra Danmarks Fiskeri- og Havundersagelser, N.S. 7:319-435.

Anonymous, 1986. Fifth Report of the Benthos Ecology Working Group. International Council for the Exploration of the Sea CM 1986/L:27, 33 pp.

Backhaus, J. O. 1989. The North Sea and the climate. Dana, 8 69-82

Basford, D. J., and Eleftheriou. A. 1988. The benthic environment of the North Sea $\left(56^{\circ}\right.$ to $\left.61^{\circ} \mathrm{N}\right)$. Journal of the Marine Biological Association of the UK, 68:125-141.

Basford, D. J., Eleftheriou, A., and Raffaelli, D. 1989. The epifauna of the northern North Sea $\left(56^{\circ}-61^{\circ} \mathrm{N}\right)$. Journal of the Marine Biological Association of the UK, 69:387-407.

Basford, D. J., Eleftheriou, A., and Raffaelli, D. 1980. The infauna and epifauna of the northern North Sea. Netherlands Journal of Sea Research, 25:166-173.

Beukema, J. J., and Cadée, G. C. 1986. Zoobenthos responses to eutrophication of the Dutch Wadden Sea. Ophelia, 26:55-64.

Cederwall, H., and Elmgren, R. 1980 . Biomass increase of benthic macrofauna demonstrates eutrophication of the Baltic Sea. Ophelia (Suppl.), 1:287-304

Colebrook, J. M., and Robinson, G. A. 1965. Continuous plankton records: seasonal cycles of phytoplankton and copepods in the north-eastern Atlantic and the North Sea. Bulletin of Marine Ecology, 6:123-139.

Cushing, D. H. 1983. Sourees of variability in the North Sea ecosystems. In North Sea dynamics. Ed. by J. Sünderman and W. Lenz. Springer-Verlag, Berlin, pp. 498-5I6.

Duineveld G C. A and Witte, H I. 1987. Report on an intercalibration exercise on methods for determining ashfree dry weight of macrozoobenthos. International Council for the Exploration of the Sea CM 1987/L:39, 6 pp.

Eisma, D., and Irion, G. 1988. Suspended matter and sediment transport. In Pollution of the North Sea. An assessment Ed. by W. Salomons, B. L. Bayne, E. K. Duursma, and U. Förstner. Springer-Verlag, Berlin, pp. 20-35.

Eleftheriou, A., and Basford, D. J. 1989. The macrobenthic infauna of the offshore northern North Sea. Journal of the Marine Biological Association of the UK, 69:123-143.

Gilson, G. 1907. Exploration de la mer sur les cótes de la Belgique. Mémoires du Musée Royal d'Historie Naturelle de Belgique, 4(1): $1-87$

Glemarec, M. 1973. The benthic communites of the European North Atlantic continental shelf. Oceanography and Marine Biology Annual Review, 1 1:263-289.

Govaere, J. C. R. Van Damme, D., Heip, C., and De Coninck L. A. P. 1980 . Benthic communities in the Southern Bight of the North Sea and their use in ecological monitoring Helgoländer wissenschaftliche Meeresuntersuchungen, 33: 507-521.

Hargrave, B. T. 1973. Coupling carbon flow through some pelagic and benthic communities. Journal of the Fisheries Research Board of Canada, 30:1317-1326.

Heip, C., Brey, T., Creutzberg, F., Dittmer, J., Dörjes, J., Duineveld, G., Kingston, P., Mair, H., Rachor, E., Rumohr, H., Thielemans, L., and Vanosmael, C. 1985. Report on an 
intercalibration exercise on sampling methods for macrobenthos. International Council for the Exploration of the Sea CM 1985/L:19,4 pp.

Heip, C.. Warwick, R. M., Carr, M. R., Herman, P. M. J., Huys, R, Smol, N., and Van Holsbeke, K. 1988. Analysis of community attributes of the benthic meiofauna of Frierfjord Langesundfjord. Marine Ecology Progress Series, 46:171-180. Hill, M. O. 1973. Diversity and evenness: $a$ unifying notation and its consequences. Ecology, $54: 427-432$

Künitzer, A., Duineveld, G. C. A., Basford, D., Craeymeersch, J. A., Dewarumez, J.-M., Dörjes, J., Eleftheriou, A., Heip, C. Herman, P. M. J., Kingston, P., Niermann, U., Rumohr, H., and de Wilde, P. A. J. 1992. The Benthic Infauna of the North Sea: Species Distribution and Assemblages. ICES Jounal of Marine Science, in press.

Lambshead, P. J. D. 1986. Sub-catastrophic sewage and industrial waste contamination as revealed by marine nematode faunal analysis. Marine Ecology Progress Series, 29:247-260.

McLain, D. H. 1974. Drawing contours from arbitrary data points. The Computer Journal, 17:318-324.

Niermann, U., Bauerfeind, E., Hickel, W., and Westernhagen, H. V. 1990. The recovery of benthos following the impact of low oxygen content in the German Bight. Netherlands Journal of Sea Research, 25:215-226.

Owens, N. J. P., Woodward, E. M. S., Aiken, J., Bellan, I. E., and Rees, A. P. 1990. Primary production and nitrogen assimilation in the North Sea during July 1987. Netherlands Journal of Sea Research, 25:143-154.

Pearson, T. H., Gray, J. S., and Johannessen, P. J. 1983. Objective selection of sensitive species indicative of pollutioninduced change in benthic communities. 2. Data analyses. Marine Ecology Progress Series, 12:237-255.

Pearson, T. H., and Rosenberg, R. 1978. Macrobenthic succession in relation to organic enrichment and pollution of the marine environment. Oceanography and Marine Biology Annual Review, 16:229-311.

Petersen, C. G. J. 1914. Valuation of the sea. II. The animal communities of the sea bottom and their importance for marine zoogeography. Report of the Danish Biological Station, 21:1-44.

Pielou, E. C. 1969. An introduction to mathematical ecology. Wiley-Interscience, New York, 286 pp.
Puls, W. 1987. Simulation of suspended sediment dispersion in the North Sea. ICES CM 1987/C:37, 24 pp.

Rachor, E. 1982. Biomass distribution and production estimates of macro-endofauna in the North Sea. International Council for the Exploration of the Sea CM 1982/L:2, 11 pp.

Rachor, E. 1990. Changes in sublittoral zoobenthos in the German Bight with regard to eutrophication. Netherlands Journal of Sea Research, 25:209-214.

Rosenberg, R. 1985. Eutrophication - the future marine coastal nuisance? Marine Pollution Bulletin, 16:227-331

Rumohr, H. 1990. Soft bottom macrofauna: collection and treatment of samples. Techniques in Marine Science 8:18 pp. International Council for the Exploration of the Sea.

Rumohr, H., Brey, T., and Ankar, S. 1987. A compilation of biometric conversion factors for benthic invertebrates in the Baltic Sea. Baltic Marine Biology Publication, 9:1-56.

Salzwedel, H., Rachor, E., and Gerdes, D. 1985. Benthic macrofauna communities in the German Bight. Veröff. Inst. Meeresforsch. Bremerhaven, 20:199-267.

Soetaert, K., and Hcip, C. 1990. Sample-size dependence of diversity indices and the determination of sufficient sample size in a high-diversity deep-sea environment. Marine Ecology Progress Series, 59:305-307.

Steele J. H. 1967 Notes on some theoretical problems in production ecology. Memorie dell' Instituto Italiano di Idrobiologia, 18 (Suppl.):383-398.

Steele, J. H. 1974. The structure of marine ecosystems. Blackwell Scientific, Oxford, $128 \mathrm{pp}$.

Stephen, A. C. 1933. Studies on the Scottish marine fauna: the natural faunistic divisions of the North Sea as shown by the quantitative distribution of the molluses. Transactions of the Royal Society of Edinburgh, 57:601-612.

Suess, E. 1980. Particulate organic carbon flux in the oceans: surface productivity and oxygen utilization. Nature, 288: 260-263.

Ursin, E. 1960. A quantitative investigation of the Echinoderm fauna of the central North Sea. Meddelelser fra Danmarks Fiskeri- og Havundersøgelser, N.S., 2(24):1-204.

Zijlstra, J. J. 1988. The North Sea ecosystem. In Continental shelves (part 27 of: D. W. Goodall, Ecosystems of the world). Elsevier, Amsterdam, pp. 231-277.

Wilkinson, L. 1988. SYGRAPH. SYSTAT, Inc., Evanston, IL. 